\title{
Taxonomic Significance of Anatomical Characters in Some Species of the Family Myrtaceae
}

\author{
Taha Y. Al-Edany ${ }^{1}$, Sahar A. A. Malik Al-Saadi ${ }^{2}$ \\ ${ }^{1}$ Department of Plant Protection, College of Agriculture, University of Basra, Basra, Iraq; ${ }^{2}$ Department of Biology, College of Sci- \\ ence, University of Basra, Basra, Iraq. \\ Email: saharmalik2010@gmail.com
}

Received February $6^{\text {th }}, 2012$; revised March $8^{\text {th }}, 2012$; accepted March $20^{\text {th }}, 2012$

\begin{abstract}
This paper elaborated the epidermis properties, transverse sections of leaves, petioles and stems of five cultivated species belong to five genera of Myrtaceae. They are Callistemon viminalis (Sol. ex Gaertn.) G. Don, Eucalyptus camaldulensis Dehnh., Myrtus communis L., Psidium guajava L. and Syzygium aromaticum (L.) Merr. It was clear that certain structural characteristics were of significant importance in separation of these taxa, such as the presence of hypodermis in the leaves of $P$. guajava, the absence of stomata from the abaxial surface of leaves of $C$. viminalis and $P$. guajava, the isobilateral mesophyll in $C$. viminalis and E. camaldulensis leaves, the wavy transverse section of stem in $C$. viminalis, the presence of more than one vascular strand in S. aromaticum petioles as well as the presence of prismatic crystals in addition to the druses in the petioles of $P$. guajava.
\end{abstract}

Keywords: Myrtaceae; Plant; Anatomy; Stem; Leaves

\section{Introduction}

Anatomical properties are indices used in taxonomical studies for more than hundred years [1]. Solereder (1908) [2] summarized a lot of anatomical characters of some dicotyledonous families followed by [3] who gave a synthesis of previous works and their own investigations of the family.

The family is of temperate, subtropical and tropical distribution chiefly centered in Australia and tropical America, including about 130 genera and 3000 species of shrubs and trees [4].

Economically the family is of considerable importance throughout the world, like the edible fruit of the guava (Psidium), spices such as the cloves (dried flower buds of Syzygium aromaticum), or cultivated domestically as ornamentals notably Eucalyptus, bottle brushes (Callistemon) and the myrtle (Myrtus communis).

Former studies of [5-10] indicated the importance of anatomical features on the palaeobotanical and taxonomical studies. Kantachok et al. (2007) [11] stated that leaf anatomical data support morphological evidence for separating taxa of Myrtaceae at the generic level.

Ali et al. (2009) [12] focused on the anatomical adaptation of leaves in the genus Eucalyptus from the Faisalabad region. While longitudinal sections of leaf axiles of Eucalyptus regnans studied by [13].

No anatomical study was performed on the family nor any kind of observations stated on it in Iraq except the morphological study of [14]. The present study is aiming to introduce an internal description of leaves, petioles and stems for five species of family to determine its taxonomic importance and clarity the interrelationship among the present members of Myrtaceae.

\section{Materials and Methods}

Fresh material of five species of Myrtaceae (Table 1) was collected from gardens throughout Basrah province. The cuticles were prepared by macerating the leaves in Jeffrey's solution (equal parts of 10\% chromium trioxide solution and concentrated nitric acid), and therefore mounted in safranin-stained glycerine jelly.

For sectioning, fresh material of leaves, petioles and stems was fixed at least 48 hours in formalin acetic acid alcohol solution (FAA) and preserved in $70 \%$ alcohol, then dehydrated in ethyl alcohol series, sectioned on a rotary microtome and stained in safranin and fast green and then mounted in canada balsam [15].

The sections were examined with Olympus $\mathrm{CH}_{4}$ light microscope and photographed with Digital camera type DCE-2. Stomatal index was calculated as mentioned by [16]. Anatomical terms used are cited from [1,16-18].

\section{Results and Discussion}

\subsection{Lamina: Epidermis and Stomata}

Measurements of epidermal cells and stomata are sum- 
marized in Table 1. There are usually differences in cell form and dimensions between the adaxial and abaxial surfaces of the leaf as well as between taxa studied.

The average length of epidermal cells in the adaxial surface ranged between 18.75 - 42.88 um and the average breadth was 11.66 - 25.00 um in Callistemon and Syzygium respectively. In the abaxial surface the average length ranged between 19.09 - 35.55 um and average breadth was 12.81 - 23.21 um in the same previous taxa respectively.

Anticlinal walls of epidermal cells exhibit a little difference between species; they are normally straight, curved sometimes and rarely sinuate (Figure 1).

Stomata are rounded or elliptic shaped present on either sides (Amphistomatic leaves) then often more numerous on the abaxial epidermis in the remaining species.

Table 1. Dimensions of epidermal cells and stomata in leaves of Myrtaceae (in micrometer).

\begin{tabular}{|c|c|c|c|c|c|c|c|c|c|c|}
\hline \multirow{3}{*}{ Taxa } & \multicolumn{4}{|c|}{ Epidermal cells } & \multicolumn{5}{|c|}{ Stomata } & \multirow{3}{*}{$\begin{array}{l}\text { Type of } \\
\text { stomata }\end{array}$} \\
\hline & \multicolumn{2}{|c|}{ Upper } & \multicolumn{2}{|c|}{ Lower } & \multicolumn{3}{|c|}{ Upper } & \multicolumn{2}{|c|}{ Lower } & \\
\hline & Length & Width & Length & Width & Length & Width & Type & Length & Width & \\
\hline $\begin{array}{l}\text { Callistemon viminalis } \\
\text { (Sol. ex Gaertn.) G. Don }\end{array}$ & $\begin{array}{l}(15-25) \\
18.75\end{array}$ & $\begin{array}{c}(7.5-15) \\
11.66\end{array}$ & $\begin{array}{c}(10-30) \\
19.09\end{array}$ & $\begin{array}{c}(10-17.5) \\
12.81\end{array}$ & - & - & A & $\begin{array}{c}(10-25.5) \\
22.32\end{array}$ & $\begin{array}{c}(20-35) \\
21.75\end{array}$ & - \\
\hline $\begin{array}{l}\text { Eucalyptus camaldulensis } \\
\text { Dehnh. }\end{array}$ & $\begin{array}{c}(12-45) \\
30.00\end{array}$ & $\begin{array}{c}(10-27) \\
14.88\end{array}$ & $\begin{array}{c}(12.5-50) \\
25.75\end{array}$ & $\begin{array}{c}(12.5-17.5) \\
13.75\end{array}$ & $\begin{array}{c}(25-35) \\
29.25\end{array}$ & $\begin{array}{c}(20-25) \\
22.50\end{array}$ & A & $\begin{array}{c}(17.5-37.5) \\
30.62\end{array}$ & $\begin{array}{c}(30-32.5) \\
30.83\end{array}$ & A \\
\hline Myrtus communis L. & $\begin{array}{c}(11-32) \\
21.50\end{array}$ & $\begin{array}{c}(10-14) \\
12.60\end{array}$ & $\begin{array}{c}(20-35) \\
27.83\end{array}$ & $\begin{array}{c}(10-15) \\
13.75\end{array}$ & $\begin{array}{c}(20-25) \\
21.60\end{array}$ & $\begin{array}{c}(10-15) \\
13.20\end{array}$ & $\begin{array}{l}\mathrm{A}+\mathrm{H} \\
+\mathrm{An}\end{array}$ & $\begin{array}{c}(16-20) \\
18.28\end{array}$ & $\begin{array}{l}(15-20) \\
18.42\end{array}$ & $\begin{array}{l}\mathbf{A}+\mathbf{H} \\
+\mathbf{A n}\end{array}$ \\
\hline Psidium guajava L. & $\begin{array}{l}(25-55) \\
35.75\end{array}$ & $\begin{array}{c}(12.5-37.5) \\
22.00\end{array}$ & $\begin{array}{c}(25-35.75) \\
31.33\end{array}$ & $\begin{array}{c}(16-23.21) \\
20.00\end{array}$ & - & - & $\begin{array}{l}\mathrm{A}+\mathrm{P} \\
+\mathrm{H}\end{array}$ & $\begin{array}{c}(15-21.6) \\
20.00\end{array}$ & $\begin{array}{c}(20-25) \\
19.50\end{array}$ & - \\
\hline $\begin{array}{l}\text { Syzygium aromaticum (L.) } \\
\text { Merr. }\end{array}$ & $\begin{array}{c}(25-67.5) \\
42.88\end{array}$ & $\begin{array}{c}(20-37.5) \\
25.00\end{array}$ & $\begin{array}{c}(25-50) \\
35.55\end{array}$ & $\begin{array}{c}(15-30) \\
23.21\end{array}$ & $\begin{array}{c}(32.5-42.5) \\
37.50\end{array}$ & $\begin{array}{c}(32.5-40) \\
36.25\end{array}$ & $\begin{array}{c}\mathrm{A}+\mathrm{H} \\
+\mathrm{P}+\mathrm{An}\end{array}$ & $\begin{array}{c}(22.5-32.5) \\
27.18\end{array}$ & $\begin{array}{l}(17.5-25) \\
21.87\end{array}$ & A \\
\hline
\end{tabular}

A = Anomocytic (Ranunculaceous); $\mathbf{H}$ = hemiparacytic; $\mathbf{P}=$ paracytic; An = Anisocytic. (The values between arches represent the mean and the values out the arches represent the minimum and maximum values).
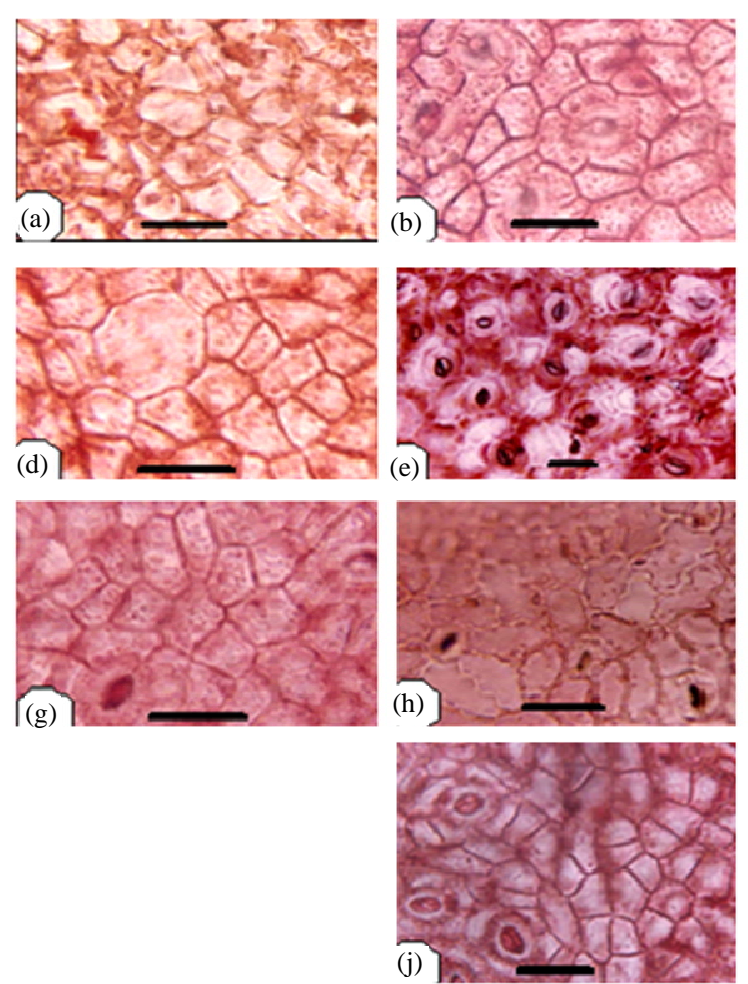
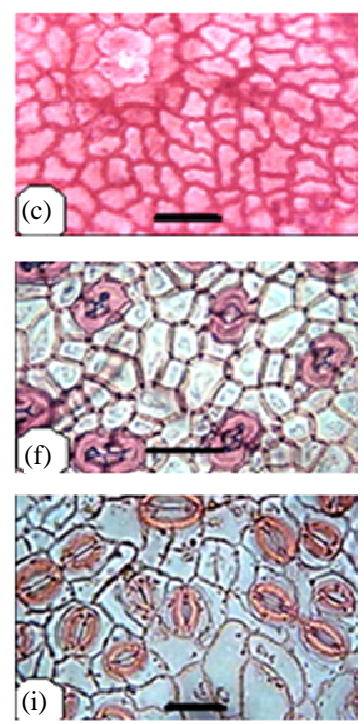

(a), (f): Callistemon viminalis; (b), (g): Eucalyptus camaldulensis; (c), (h): Myrtus communis; (d), (i): Psidium guajava; (e), (j): Syzygium aromaticum; (a)-(e): Upper epidermis; (f)-(j): Lower epidermis, (scale 25 um).

Figure 1. Surface view of leaf epidermis. 
Although ranunculaceous stomata are present in all taxa but Myrtus, Psidium and Syzygium showed another types in addition to the ranunculaceous type (Table 1). Guard cells are kidney shaped. Metcalf and Chalk (1950) [3] supported this truth when they pointed that stomata in Myrtaceae are usually ranunculaceous except in a few species. [11,19] found nearly similar types when they observed three types of stomata: anomocytic, paracytic and anisocytic.

Larger number of epidermal cells is often recorded on the upper epidermis ranging between 127.2 and 420 cells $/ \mathrm{mm}^{2}$, while it was ranging between 132 and 302 cells $/ \mathrm{mm}^{2}$ on the lower epidermis in Callistemon vimi- nalis and Syzygium aromaticum respectively i.e. appositively related with their dimensions. Stomatal complexes can be believed as a significant character in the identification of species.

\subsection{Transverse Sections}

\subsubsection{Transverse Sections of Lamina}

Two types of mesophyll has been recognized, isobilateral in Callistemon viminalis and Eucalyptus camaldulensis or dorsiventral in the other taxa (Figure 2) in agreement with the work of [11]. Souza et al. (1999) [20] mentioned that mesophyll of Eucalyptus camaldulensis is bifacial.

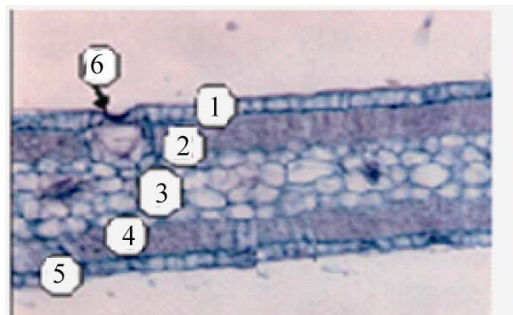

(a)

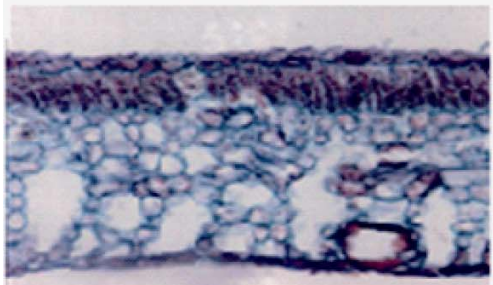

(d)

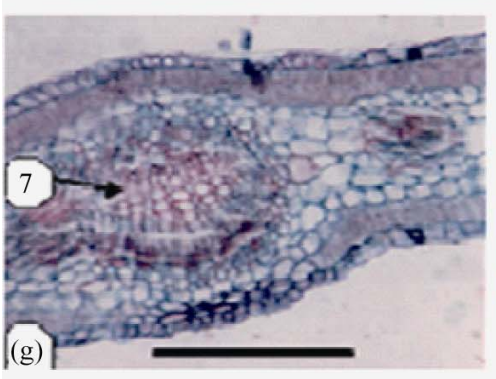

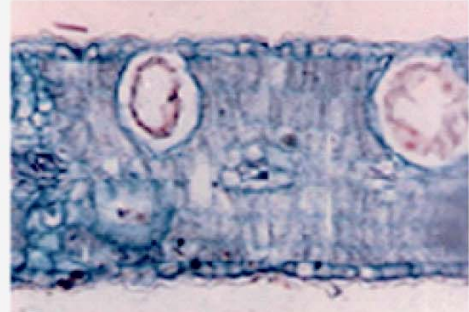
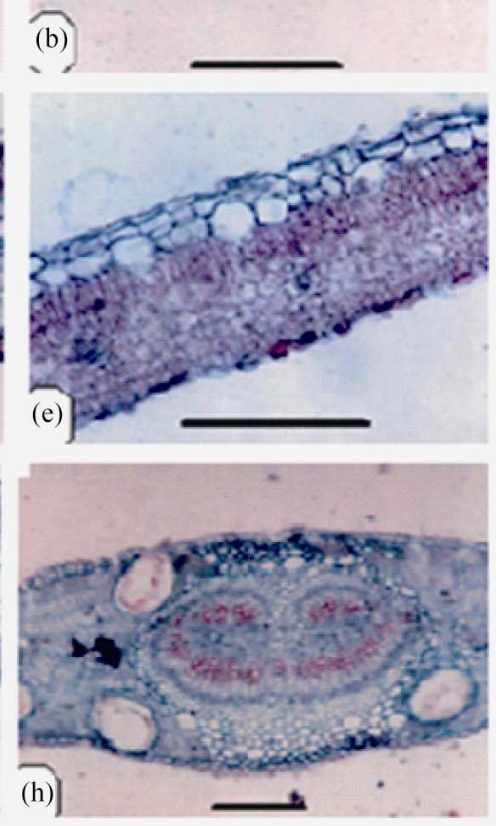
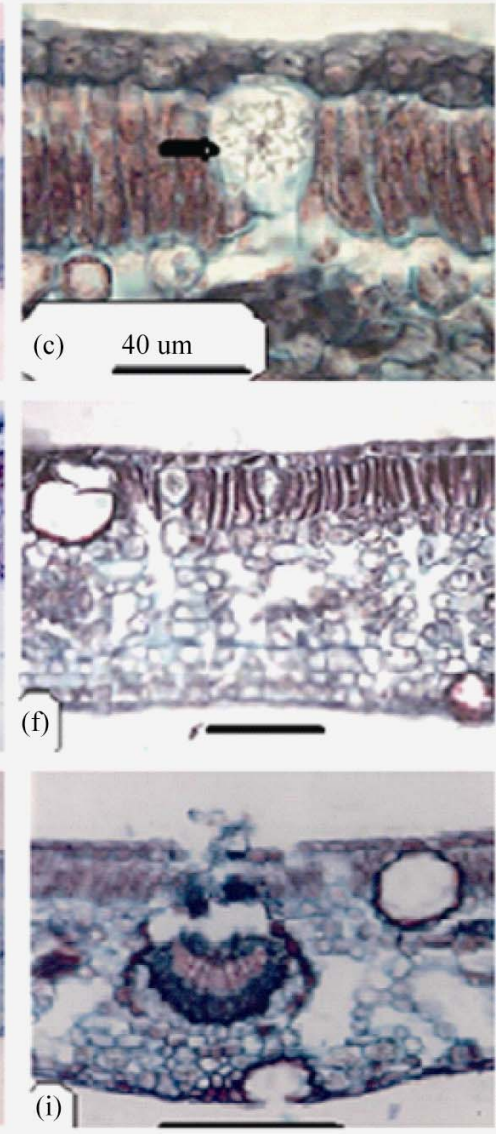

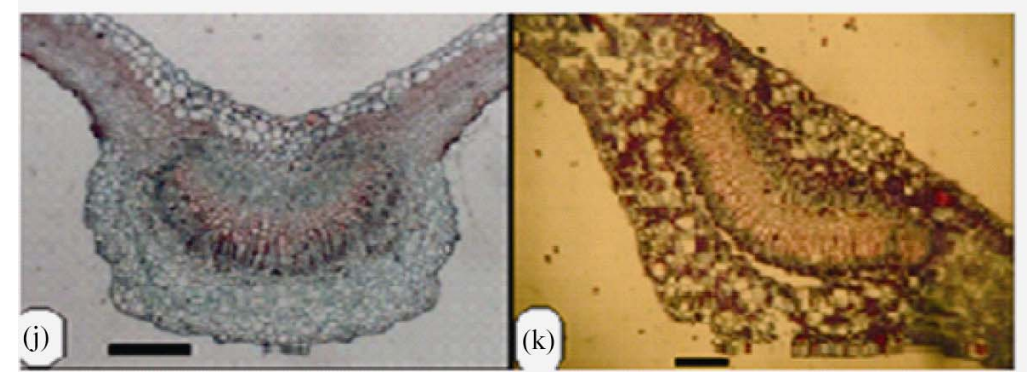

(a), (h): Eucalyptus camaldulensis; (b), (g): Callistemon viminalis; (c): druses in hypodermis of Myrtus communis; (d), (i): Myrtus communis; (e), (j): Psidium guajava; (f), (k): Syzygium aromaticum; 1: upper epidermis; 2: palisad layer; 3: spongy layer; 4: palisad layer; 5: lower epidermis; 6: secretory canal; 7: vascular bundle; (a-f: Lef lamina; g-k: midribs (scale $200 \mathrm{um}$ ).

Figure 2. Transverse section of leaf lamina and midribs. 
while in Eugenia pyriformis the mesophyll was dorsiventral [21], but [3,4] stated that leaves in Eucalyptus and Eugenia sometimes show the two structures depending on the case of these leaves if are vertical or horizontal.

Thickness of lamina ranged between 180 um in Callistemon and 435 um in Syzygium. Cuticle thickness occurred between 3.95 um and 10.35 um in Callistemon and Eucalyptus respectively (Table 2). This increase in cuticle thickness in the latter taxon may be due to the presence of wax in addition to cuticle that [3] mentioned that epidermis coated with wax in some species of Eucalyptus.

Epidermal cells are square-shaped or rectangular, uniserriate. Hypodermis present below the upper epidermis in one species (Psidium guajava).

Mesophyll of 1 - 2 layers of palisade cells and several rows (up to 15) of compact or loose spongy tissue, or two layers of palisade cells on adaxial and abaxial surfaces enclosing spongy tissue (Table 2). Stone cells were recorded in the mesophyll of Syzygium aromaticum.

Mid-rib usually grooved from above erect downward, curved or flattened in both directions, supplied with one bicollateral vascular strand variable in shape according to species ranging between ovate, heart-shaped or U-shaped (Figure 2, Table 3).

Secretory cavities and cells containing tannin are very common in all unlignified tissues in the taxa investigated. Metcalf and Chalk [3] pointed to similar structures. Esau (1977) [17] stated that tanniniferous idioblasts and secretory cavities occur in many families including Myrtaceae. Oil cavities located close to both surfaces, glandular, and lined with epithelial-like cells (Figure 2). Druses crystals are very common in all species in the mesophyll and cortex of leaves, petiols and stems. Prismatic crystals are seen in the leaf close to the mid-rib in Callistemon viminalis and Pisidium guajava.

There are some anatomical similarities among the leaves, such as striated cuticle, dorsiventral mesophyll, a midrib with a bicollateral vascular strand in an open arc that surrounded by a sclerenchymatic sheath, secretary canal occurred in the sub epidermis, druses and prismatic crystals of calcium oxalate and phenolic compounds [21, 22]. Secretory cavities developed from single epidermal cells, the origin of it was initially schizogenous but ultimately lysigenous at maturity with a breakdown of all the secretory cells within the gland lumen [23], while according to [24] reported that these cavities were located near the epidermis, the origin was from the epidermal meristem without participation of the ground meristem.

\subsubsection{Transverse Sections of Petioles}

Petioles were variable in length and shape ranging from elliptic to ovoid to semicircular to winged in the trans- verse section covered with simple hairs in all species. Trichomes of Psidium guajava are simple and glandular hairs (Figure 3).

Epidermis is one layered, square or rectangular shaped, covered with a layer of cuticle of variable thickness, followed by a cortex of 2 - 3 rows of collenchyma, 2 - 4 rows of chlorenchyma and several rows of parenchyma ranging between $4-7$. Large secreting cavities and druses are very common in cortical region in Callistemon viminalis and P. guajava are characterized by the presence of prismatic crystals rectangular (Table 4).

According [21] vascular bundle in a centric arrangement in the petiole has open arc, which similar with the open arc observed in the present wok.

Vascular system with single, principal arc-shaped vascular strand, widely open, in Callistemon, $U$-Shaped in Psidium, Myrtus and Syzygium, heart-shaped in Eucalyptus. Syzygium and Callistemon were characterized by the presence of additional strands in the wings. Vascular strand is surrounded by sclerenchymatic tissue.

\subsubsection{Transverse Sections of Stems}

Anatomical characters of stems are represented in Table 5. Outline is semi-circular (Myrtus), quadrangular (Syzygium), quadrangular with wings (Eucalyptus and Psidium) or wavy (Callistemon) (Figures $\mathbf{4}$ and $\mathbf{5}$ ).

Epidermis uniserriate covered with a thin or thick layer of cuticle followed by multilayered cortex rich of wide secreting cavities and taniniferous cells. Three types of distinct tissues are recognized in cortex, chlorenchyma, collenchyma and parenchyma in taxa under investigation except the taxa Eucalyptus, Myrtus and Syzygium where chlorenchyma is absent.

Vascular tissue is a continuous bicollateral cylinder in all species. Pith presenting the centre of stem composed of parenchymatous storage cells of isodimetric to polyhederal thin layered cells with more or less large intercellular spaces. Cells are rich of druses crystals. Cell dimensions increases towards the center of stem.

Although the five species investigated belong to five distinct genera, [22] reported that the morphological features of the seed surface sculpture as revealed by SEM show no clear boundaries between the species of the same tribe except minor variation in the anticlinal and periclinal walls, so that the anatomical structures inform additional features for distinction of these species. Some are of high taxonomic significance such as the presence of hypodermis in leaves of Psidium guajava, the absence of stomata in the abaxial epidermis of Callistemon viminalis and $P$. guajava, the occurance of isobilateral and dorsiventral leaf type appears to be a good diagnostic characteristic for the generic level, the wavy outline of $C$. viminalis stem and the presence of more than one vascular strand in the petiole of $C$. viminalis and S. aromatic- 


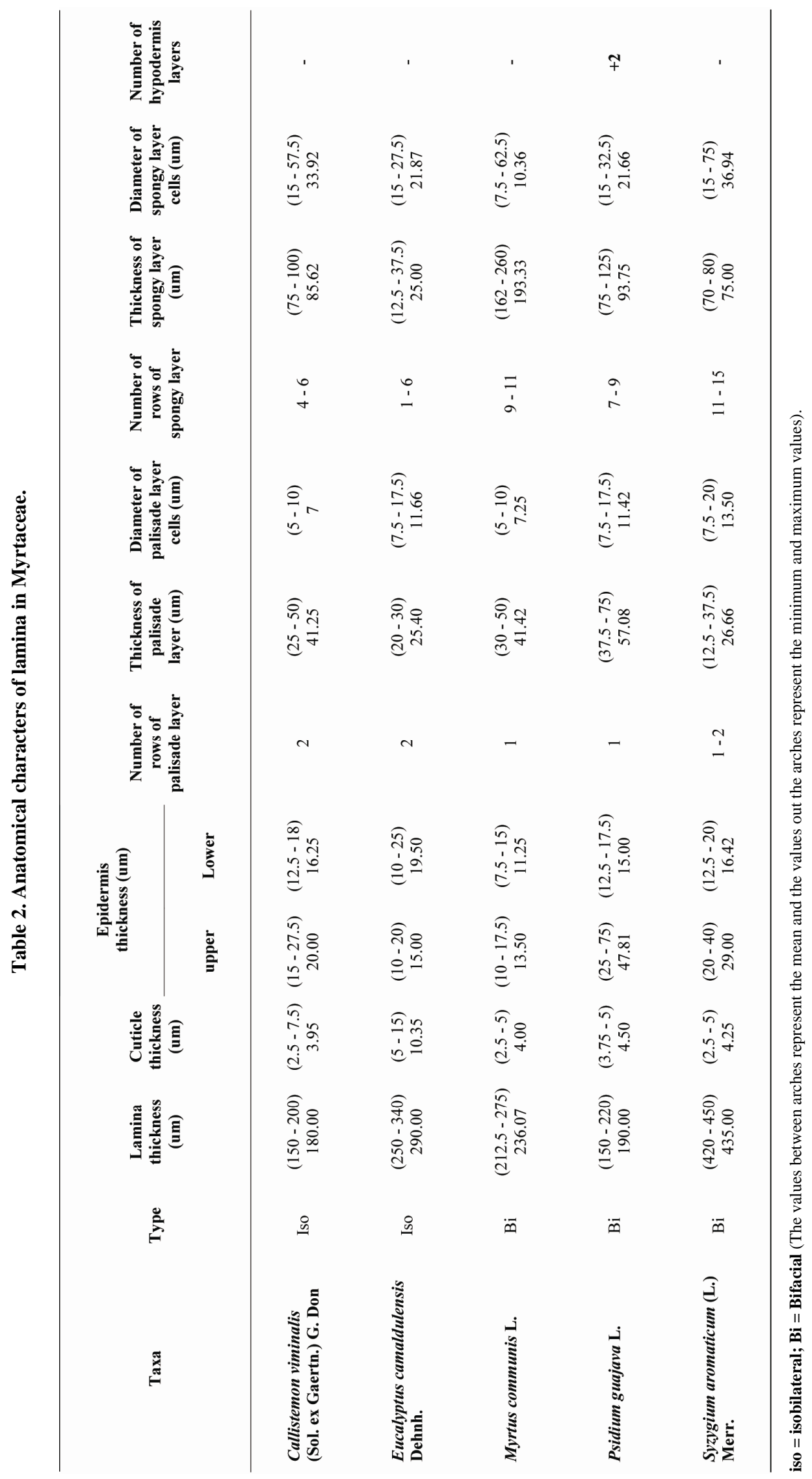


Table 3. Anatomical characters of mid-rib Myrtaceae (in micrometer).

\begin{tabular}{|c|c|c|c|c|c|c|}
\hline Taxa & Mid-rib shape & Thickness & $\begin{array}{l}\text { Length of } \\
\text { wood arms }\end{array}$ & $\begin{array}{l}\text { Number of } \\
\text { wood arms }\end{array}$ & $\begin{array}{l}\text { Number of vessels } \\
\text { in the arm }\end{array}$ & $\begin{array}{l}\text { Mid-rib vascular } \\
\text { bundle shape }\end{array}$ \\
\hline Callistemon viminalis (Sol. ex Gaertn.) G. Don & Semi flat & $\begin{array}{c}(275-350) \\
312.5\end{array}$ & $\begin{array}{c}(125-212.5) \\
168.75\end{array}$ & $18-24$ & $6-12$ & Ovate \\
\hline Eucalyptus camaldulensis Dehnh. & Semi flat & $\begin{array}{l}(675-700) \\
\quad 687.5\end{array}$ & $\begin{array}{c}(56.3-87.3) \\
\quad 70.83\end{array}$ & $46-50$ & $3-6$ & Heart-shaped \\
\hline Myrtus communis L. & Erect & $\begin{array}{c}(257-287.5) \\
270.25\end{array}$ & $\begin{array}{c}(112.5-175) \\
145.83\end{array}$ & $15-18$ & $3-7$ & U-shaped \\
\hline Psidium guajava $\mathrm{L}$. & Strongly erect & $\begin{array}{l}(780-870) \\
850\end{array}$ & $\begin{array}{c}(50-225) \\
158.33\end{array}$ & $51-56$ & $4-14$ & U-shaped \\
\hline Syzygium aromaticum (L.) Merr. & erect & $\begin{array}{c}(950-1100) \\
1075\end{array}$ & $\begin{array}{c}(162.5-250) \\
213.50\end{array}$ & $60-63$ & $11-13$ & U-shaped \\
\hline
\end{tabular}

The values between arches represent the mean and the values out the arches represent the minimum and maximum.
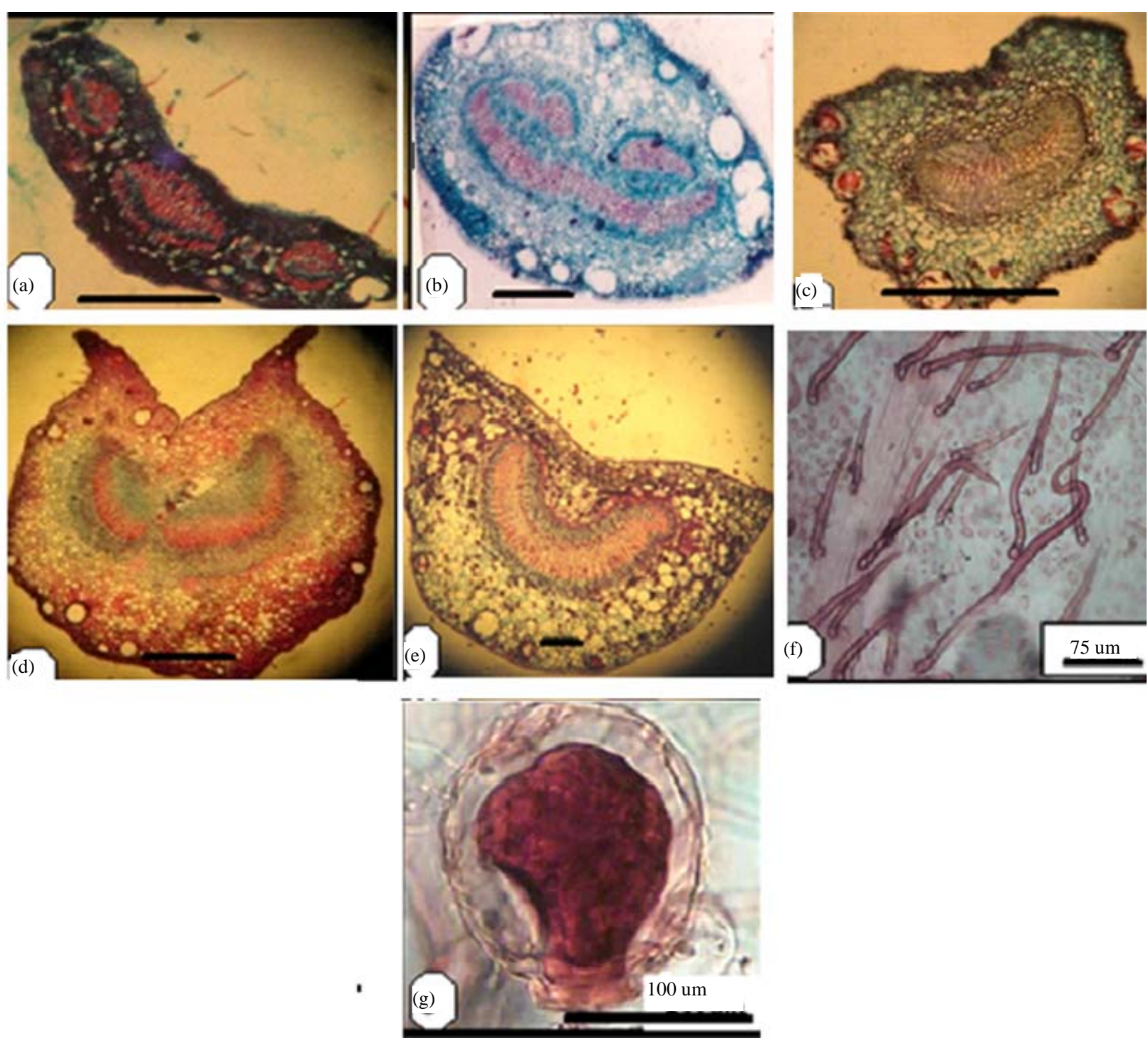

(a): Callistemon viminalis; (b): Eucalyptus camaldulensis; (c): Myrtus communis; (d): Psidium guajava;

(e): Syzygium aromaticum; (f): simple trichomes; (g): glandular trichomes.

Figure 3. Transverse section of petioles (scale $200 \mathrm{um}$ ). 

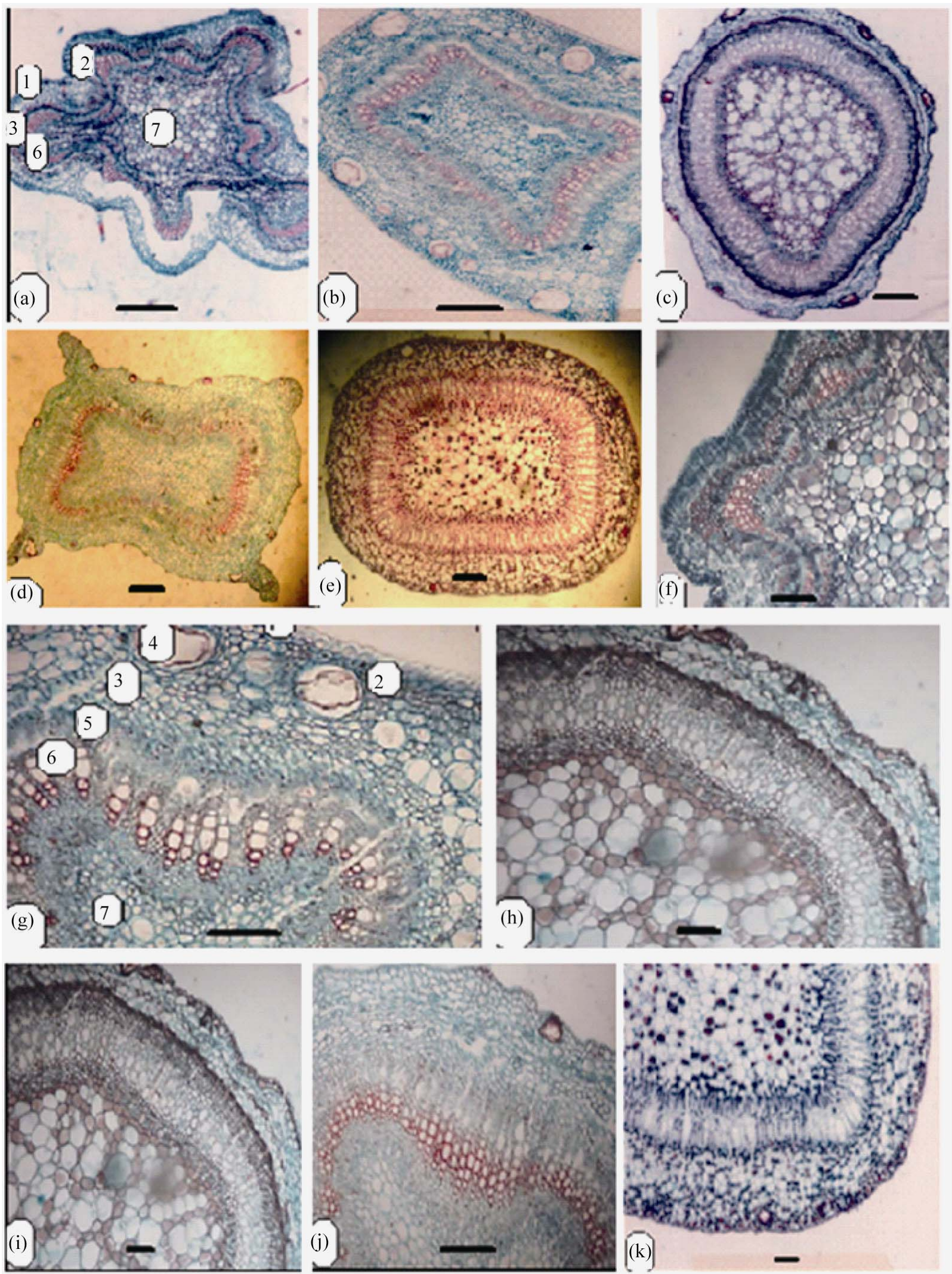

(a), (g): Callistemon viminalis; (b), (h): Eucalyptus camaldulensis; (c), (i): Myrtus communis; (d), (j): Psidium guajava; (e), (k): Syzygium aromaticum; 1: Epidermis; 2: collenchyma; 3: parenchyma; 4: secretory canal; 5: phloem; 6: xylem; 7: pith. (a-e): scale 200 um, f-k: scale 50 um)

Figure 4. Transverse section of stems (scale $50 \mathrm{um}$ ). 
Table 4. Anatomical characters of petiole in Myrtaceae (in micrometer).

\begin{tabular}{|c|c|c|c|c|c|c|c|}
\hline Taxa & Shape & Thickness & $\begin{array}{c}\text { Number of } \\
\text { vascular bundle }\end{array}$ & $\begin{array}{l}\text { Number of } \\
\text { wood arms }\end{array}$ & $\begin{array}{l}\text { Length of } \\
\text { wood arms }\end{array}$ & $\begin{array}{l}\text { Petiole vascular } \\
\text { bundle shape }\end{array}$ & Crystal shape \\
\hline $\begin{array}{l}\text { Callistemon viminalis } \\
\text { (Sol. ex Gaertn.) G. Don }\end{array}$ & Elliptic & $\begin{array}{c}(307.5-317.5) \\
312.50\end{array}$ & 1 & $\begin{array}{c}(15-22) \\
17.00\end{array}$ & $\begin{array}{c}(172.5-180) \\
175.83\end{array}$ & Arc-shaped & $\mathbf{D}+\mathbf{P}$ \\
\hline $\begin{array}{l}\text { Eucalyptus camaldulensis } \\
\text { Dehnh. }\end{array}$ & Ovoid & $\begin{array}{l}(670-680) \\
675.00)\end{array}$ & 1 & $\begin{array}{c}(44-52) \\
47.00\end{array}$ & $\begin{array}{c}(250-320) \\
290.00\end{array}$ & Heart-shaped & D \\
\hline Myrtus communis L. & Winged & $\begin{array}{c}(292.5-305) \\
300.00\end{array}$ & 1 & $\begin{array}{c}(20-27) \\
25.00\end{array}$ & $\begin{array}{c}(145-150) \\
147.50\end{array}$ & U-Shaped & D \\
\hline Psidium guajava $\mathrm{L}$. & Winged & $\begin{array}{l}(720-760) \\
740.00\end{array}$ & 1 & $\begin{array}{c}(55-62) \\
57.00\end{array}$ & $\begin{array}{c}(300-350) \\
325.00\end{array}$ & U-Shaped & $\mathbf{D}+\mathbf{P}$ \\
\hline $\begin{array}{l}\text { Syzygium aromaticum (L.) } \\
\text { Merr. }\end{array}$ & Semicircular & $\begin{array}{c}(920-960) \\
943.33\end{array}$ & $2-3$ & $\begin{array}{c}(46-50) \\
47.00\end{array}$ & $\begin{array}{c}(290-320) \\
303.33\end{array}$ & U-Shaped & D \\
\hline
\end{tabular}

D = Druses, $\mathbf{P}=$ Prismatic; The values between arches represent the mean and the values out the arches represent the minimum and maximum.

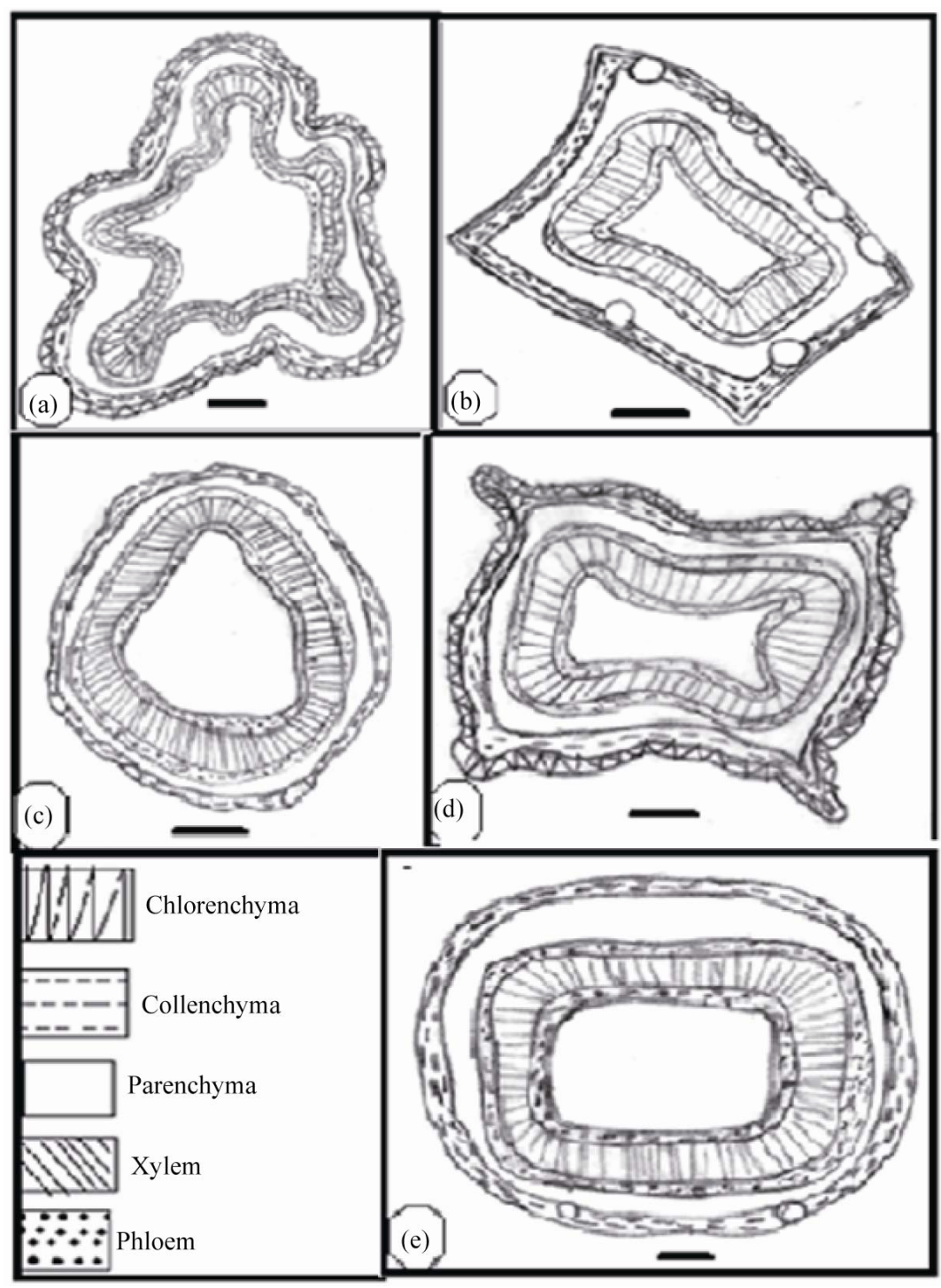

(a): Callistemon viminalis; (b): Eucalyptus camaldulensis; (c): Myrtus communis; (d): Psidium guajav; (e): Syzygium aromaticum.

Figure 5. Transverse section of stem (scale $200 \mathrm{um}$ ). 


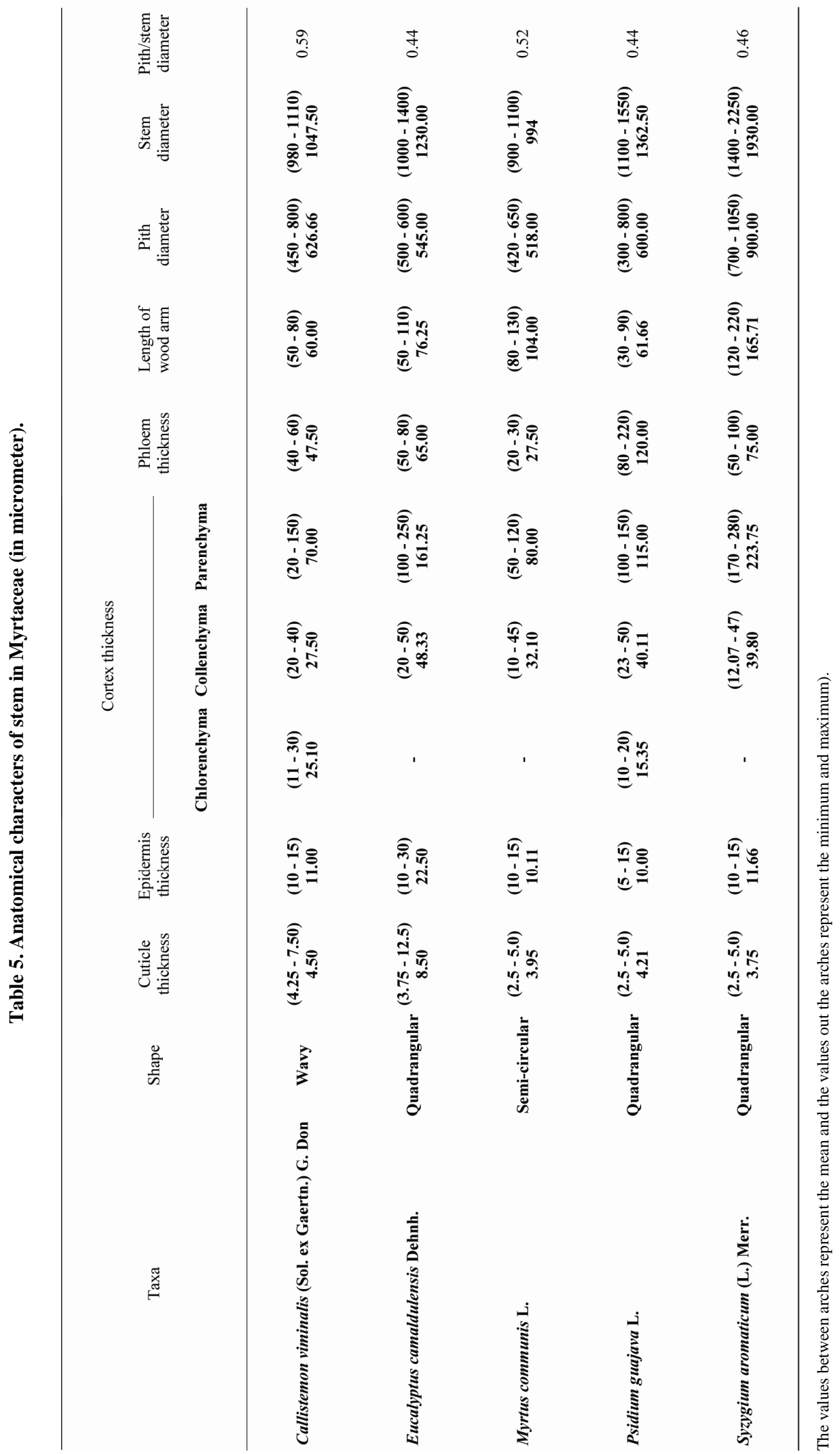


cum, as well as the presence of prismatic crystal in the cortex of petiole of $P$. guajava and $C$.viminalis, in addition to the druses and the presence of glandular trichomes in C. viminalis and P. guajava. This phenomenon has not been reported before.

\section{REFERENCES}

[1] A. E. Radford, W. C. Dikison, J. R. Massey and C. R. Bell, "Vascular Plants Systematics," Harper and Row, New York, 1974.

[2] H. Solereder, "Systematic Anatomy of the Dicotyledons," Clarendon Press, Oxford, Vol. 1, 1908, pp. 350-355.

[3] C. R. Metcalf and L. Chalk, "Anatomy of Dicotyledons," Clarendon Press, Oxford, Vol. 2, 1950.

[4] L. Watson and M. J. Dallwitz, "The Families of Flowering Plants,” 1992. http//deltaintkey.com

[5] K. J. Hammadi, A. A. Al-Mayah and I. M. Al-Rubaie, "Comparative Anatomical Study of Some Genera of Polygonaceae in Iraq,” Journal of Basrah Researches, Vol. 28, 2002, pp. 90-109.

[6] A. A. Al-Mayah and K. J. Hammadi, "Vegetative Anatomy of Polygonum (Polygonaceae)," Basrah Journal of Science, Vol. 16, No. 1, 1998, pp. 55-62.

[7] I. M. Al-Rubaie, "Comparative Anatomical Study of Some Species of Malvaceae in Iraq," Journal of Basrah Researches, Vol. 28, 2002, pp. 90-109.

[8] C. M. V. Cardoso and M. G. Sajo, "Vescularizacao Foliar ea Identificacao de Species de Eugenia L. (Myrtaceae) da Bacia Hidrografica do Rio Tibagi,” Revista Brasileira de Botânica, Vol. 27, No. 1, 2004, pp. 47-54. doi:10.1590/S0100-84042004000100006

[9] A. H. Lafta, S. A. Al-Saadi and T. Y. Al-Edany, "Taxonomic Significance of Anatomical Characters of Different Species of the Family Chenopodiaceae in Iraq," Basrah Journal of Science (B), Vol. 23, No. 1, 2005, pp. 59-73.

[10] T. Y. Al-Edany, "Comparative Anatomical Study of Some Species of the Family Verbenaceae in Iraq," Basrah Journal of Agriculture Science, Vol. 18, No. 1, 2005, pp. 35-51.

[11] C. Kantachot, P. Chantaranothai and A. Thammathaworn, "Contribution to the Leaf Anatomy and Taxonomy of Thai Myrtaceae,” The Natural History Journal of Chulalongkorn University, Vol. 7, No. 1, 2007, pp. 35-45.

[12] I. Ali, S. Q. Abbas, M. Hameed, N. Naz, S. Zafar and S. Kanwal, "Leaf Anatomical Adaptations in Some Exotic Species of Eucalyptus L’Hér Myrtaceae,” Pakistan Jour- nal of Botany, Vol. 41, No. 6, 2009, pp. 2717-272.

[13] D. A. Waters, G. E. Burrows and J. D. Harper, "Eucalyptus regnans (Myrtaceae): A Fire-Sensitive Eucalypt with a Resprouter Epicormic Structure," American Journal of Botany, Vol. 97, No. 4, 2010, pp. 1-12. doi:10.3732/ajb.0900158

[14] C. C. Townsend and E. Guest, "Flora of Iraq," Ministry of Agriculture of Iraq, Vol. 4, 1980.

[15] D. A. Johansen, "Plant Microtechnique," McGrow Hill, New York, 1940.

[16] D. L. Ditcher, "Approaches to the Identification of Angiosperm Leaf Remains,” Botanical Review, Vol. 4, No. 1, 1974, pp. 1-157.

[17] K. Esau, “Anatomy of Seed Plants,” John Wiley and Sons, New York, 1977, p. 550.

[18] R. Melville, "The Terminology of Leaf Architecture," Taxon, Vol. 25, No. 5-6, 1976, pp. 549-561. doi: $10.2307 / 1220108$

[19] K. H. Hussin, D. F. Cutter and D. M. Moore, "Leaf Anatomical Studies in Eugenia L. (Myrtaceae) Species from Malay Peninsula," Botanical Journal of the Linnean Society, Vol. 110, No. 2, 1992, pp. 137-156. doi:10.1111/j.1095-8339.1992.tb00287.x

[20] G. M. Souza, A. N. Goncalves and M. Almeida, "Water Deficit in Relation to Leaf and Stem Anatomy of Eucalyptus camaldulensis Dehn. Shoots Cultivated in Vitro," Scientia Agricola, Vol. 56, No. 3, 1999, pp. 33-45. doi:10.1590/S0103-90161999000300030

[21] L. Armstrong, M. R. Duarte and O. Gomes, "Morphoanatomy of the Leaf and Stem of Eugenia pyriformi," Revista Brasileira de Farmacognosia, 2012, in press. doi:10.1590/S0102-695X2012005000022

[22] M. E. Tantawy, "Morpho-Anatomical Study on Certain Taxa of Myrtaceae,” Asian Journal of Plant Sciences, Vol. 3, No. 3, 2004, pp. 274-285. doi:10.3923/ajps.2004.274.285

[23] D. Ciccarelli, F. Garbari and A. M. Pagni, "The Flower of Myrtus communis (Myrtaceae): Secretory Structures, Unicellular Papillae, and Their Ecological Role,” Flora, Vol. 203, No. 1, 2008, pp. 85-93. doi:10.1016/j.flora.2007.01.002

[24] S. M. Gomes, N. S. Somavilha, K. M. Bezerra, S. C. Miranda, P. S. Carvalho and D. G. Ribeiro, "Anatomia Foliar de Species de Myrtaceae: Contribuicoes a Taxonomia e Filogenia," Acta Botanica Brasilica, Vol. 23, No. 1, 2009, pp. 223-238. doi:10.1590/S0102-33062009000100024 